\author{
Eerika Albrecht ${ }^{\mathrm{a}}$
}

\title{
Suopolitiikka Suomessa - paikallinen liikehdintä, deliberatiivinen hallinta ja argumentit
}

\author{
Väitöstilaisuuden lectio praecursoria \\ Itä-Suomen yliopisto, 28.9.20 I 8
}

Suo on olennainen osa suomalaista luontoa ja merkitsee monelle luonnon monimuotoisuutta. Suolla on ollut myös huomattava merkitys suomalaisen yhteiskunnan kehitykselle osana elinkeinoelämää ja kulttuuria. Soista puhuttaessa voidaankin painottaa joko energiaomavaraisuutta ja turvetta voimalaitosten raaka-ainereservinä tai ilmastonmuutoksen hillintää ja luonnon monimuotoisuutta.

Suo- ja turvemaat peittävät kolmanneksen Suomen maapinta-alasta. Tuosta noin 8,7 miljoonan hehtaarin turvemaapinta-alasta yli puolet on ojitettu. Jäljellä oleville suoalueille kohdistuu monenlaisia intressejä, joko turvetuotannon muodossa, luonnon monimuotoisuuden turvaajana tai virkistyskäytön kohteena. Soihin liittyvät maankäyttökysymykset ja ympäristökysymykset ovat ajankohtaisia 2010-luvulla. Kysymysten taustalla vaikuttavat teollistumisen myötä tapahtuneet maankäytön muutokset ja vesistöjen tilan huonontuminen. Luonnontilaisten soiden märä on voimakkaasti vähentynyt metsätalouden ja maatalouden ojitusten sekä turvetuotannon seurauksena. Suon eri käyttömuotojen väliset ristiriidat ovat lisääntyneet soiden luontoarvojen ja virkistyskäytön korostumisen seurauksena.

Turpeennosto on ojituksen ohella suoluontoon voimakkaimmin vaikuttava ihmisen aiheuttama toimenpide. Puitteet turpeen teolliselle käytölle luotiin 1970-luvun öljykriisin seurauksena ja tuolloin turpeen energiakäyttöä lisättiin merkittävästi. Pyrkimyksenä oli energiaomavaraisuus ja huoltovarmuuden lisääminen, jolloin turve kotimaisena polttoaineena nousi kiinnostuksen kohteeksi. GTK ryhtyi kartoittamaan Suomen turvevaroja ja VAPO Oy:lle annettiin tehtäväksi turpeen energiakäytön kehittäminen (Ruuskanen 2010, 33.).

Turpeen poltto on jälleen ajankohtainen ympäristöpolitiikan kysymys, kun puolueet valmistelevat kilpaa suosituksia turpeen polton loppumiseksi niin kutsuttujen ilmastovaalien alla. Ilmastonmuutos on aikamme suuria haasteita, joka on aiheuttanut ja tulee myös tulevaisuudessa aiheuttamaan vakavia riskejä luonnon ja ihmisen hyvinvoinnille. Puolueet väittelevät vuosikymmenestä jolloin turpeen käytöstä tulisi luopua. Tämän tulisi tapahtua, joko 2020, 2030 tai 2040 -luvun loppuun mennessä. Myös Euroopan komission energiapolitiikan suuntaviivat vuoteen 2050 määrittävät tavoitteeksi turpeen käytöstä luopumisen. Ilmastovaikutusten kannalta on tärkeää, että turve ei korvaudu kivihiilellä tai muulla fossiilisella polttoaineella. 
Suopolitiikan muutos on ollut nopeaa. Turve määriteltiin vielä vuonna 2010 työ- ja elinkeinoministeriön tilaamassa raportissa uusiutuvaksi biomassapolttoaineeksi. Samalla todettiin, että hallitustenvälinen ilmastonmuutospaneeli IPCC luokittelee turpeen omaksi polttoaineluokakseen. Kotimaisen biomassapolttoaineen käyttöä edistettiin tuolloin Suomen energiapolitiikassa. Edelleen turve koetaan suomalaisen energiapolitiikan kentällä tärkeänä työllistäjänä ja energiavarmuuden turvaajana.

Suo- ja turvepolitiikkaa, sekä turvetta energiapolitiikan osana tutkivan yhteiskuntatieteellisen ympäristöntutkimuksen kenttä on kapea. Turpeennoston historiaa, turpeennoston ympäristölupajärjestelmää, turpeeseen liittyviä energiapolitiikan argumentteja, turpeennoston yhteiskunnallista hyväksyttävyyttä ja suo-ojituksia on käsitelty muun muassa historian, sosiologian, maantieteen ja ympäristöoikeuden alaan sijoittuvissa tutkimuksissa (mm. Tanskanen 2000; Ruuskanen 2010, Lempinen 2013, Pölönen \& Halinen 2014, Konttinen ym. 2018). Siten tutkimukseni on merkittävä lisä tähän yhteiskunnallisen suotutkimuksen kenttään.

Tutkimukseni tarkastelee yhteiskunnallisen muutoksen seurauksena syntynyttä turvevarojen hallinnan kestävyyden uudelleenmäärittelyä suuntaamalla huomion politiikkaprosesseihin, paikallisiin konflikteihin sekä vuorovaikutteiseen ja osallistavaan hallintaan. Samalla tutkimukseni erittelee suomalaisen soidensuojelupolitiikan vuorovaikutuksen kenttää kiinnittämällä huomiota kielelliseen vuorovaikutukseen ja argumentaatioon vaikuttamisen välineenä. Tällöin kiinnostuksen kohteena ovat perustelut, joilla soidensuojelun eri politiikkakeinoja ja paikallista toteutusta tuetaan tai vastustetaan. Käsityksiä suon käyttömuodoista ja soidensuojelupolitiikan toteuttamisesta on laajalti argumentoitu puolesta ja vastaan.

\section{Turvekiistat}

Väitänkin, että turpeennoston herättämä laaja vastustus on etenkin 2000-luvun ilmiö. Turvekiistat kytkeytyvät maaseudun muutokseen, sillä maalla asujat haluavat elää lähellä luontoa ja virkistäytyä. Tämän vuoksi luonnon puolesta halutaan myös toimia. Toiminta turvekiistassa rinnastuu oman elintilan puolustamiseen ja kyläyhteisön hyvinvoinnin turvaamiseen.

2000-luvun turvekiistoille mielenkiintoinen piirre on, että niitä käydään ympäristölupaprosessien yhteydessä oikeusistuimissa. Tämä kertoo suomalaisten suoaktiivien vahvasta luottamuksesta oikeusvaltioon. Ympäristölupajärjestelmä on mahdollistanut kiistojen käymisen oikeusteitse, sillä ympäristölupapäätöksestä on mahdollista valittaa Vaasan hallintooikeuteen ja tämän jälkeen korkeimpaan hallinto-oikeuteen. Ympäristönsuojelulakiin sisällytetty laaja valitusoikeus on merkittävä näiden yksittäisten soiden puolesta käytyjen kamppailujen kannalta. Naapuruus ei yksin oikeuta valituksen tekemiseen, vaan yhdistyksillä, kunnilla ja elinkeino-, liikenne- ja ympäristökeskuksilla on mahdollisuus vedota hallintotuomioistuimiin. Luonnonsuojelijat näkevät hallinto-oikeudessa käytävät turvekiistat tehokkaaksi viivytyskamppailuksi luonnontilaisten soiden suojelussa. Turvetuottajat taas ovat tunnistaneet, että polttoturve on hiipuva toiminnanala ja etsivät vaihtoehtoisia toiminnanaloja biotaloudesta.

Turvekiistoissa muodostuu merkitykselliseksi, miten paikalliset toimijat hankkivat oikeudessa tarvittavaa erityisosaamista sekä mitkä ovat heidän mahdollisuutensa sitoutua ihmisiässä merkittäväksi ajaksi. Pahimmillaan kiistat kestävät vuosikymmeniä, ja sinä aikana paikallisyhteisöissä, yhteiskunnallisilla areenoilla ja sääntely-ympäristössä tapahtuu muutosta (Albrecht 2015; Albrecht \& Ratamäki 2016). Ympäristölupa-asiassa valittaminen vaatii vähintäänkin maallikkotason tietotaitoa, kuinka oikeusistuimiin vedotaan, ja usein asiantuntijan apua pätevän argumentin löytämiseksi. Tämä edellyttää luonnontieteellistä asiantuntemusta, sillä uhanalaisten lajin lisääntymis- ja levähdyspaikat, sekä uhanalaiset biotoopit voivat toimia ympäristönsuojelulain mukaisena argumenttina.

Tutkimuksessani lähestyn turvekysymystä paikallisten tapausesimerkkien kautta, joissa paikalliset asukkaat vastustavat turvetuotannon aloittamista lähisoillaan. Turvetuotantoon liittyvät ympäristökiistat ovat usein hyvin paikallisia, vaikkakin omaavat kytköksiä kansallisen tason energiapolitiikkaan ja ylikansallisen tason ilmastopolitiikkaan. Kiista muodostuu tutkimuksessani turveteollisuuden edustajien ja paikallisten suon säilyttämistä ajavien asukkaiden, kyläyhdistysten, kalastuskuntien luonnonsuojelujärjestöjen välille. Ympäristöjärjestöt vaativat 
turvetuotannon päästöistä luopumista ja paikalliset aktiivit vastustavat kotiseutunsa tärkeiden soiden käyttöönottoa.

Kiinnostavaa on millaisia turvekiistoja paikallistasolle on muodostunut ja miten paikallisyhteisön jäsenet toimivat kiistan osapuolina. Nostan tarkastelun kohteeksi Julkunevan turvekiistan Vetelissä, Keski-Pohjanmaalla, sekä Viurusuon turvekiistan Outokummussa Pohjois-Karjalassa. Nämä ovat luonteeltaan hyvin samantyyppisiä, mutta nostavat tapaustutkimuksina esille 2000-luvun ympäristökiistojen ominaispiirteitä, joista tieteellisen tiedon käyttö ja perustelujen muotoilu eri yleisöille ja vaikuttaminen politiikan eri areenoilla ovat keskeisimpiä.

\section{Soiden suojelu}

Lisäksi tarkastelen soidensuojelupolitiikan määrittelykamppailuja ja toimijakenttää osana demokraattista osallistumista ja osallistamista sekä deliberaatiota korostavaa ympäristöhallinnan tutkimusperinnettä (mm. Dryzek 2013, 15; Bäckstrand \& Kronsell 2015, 12). Deliberaatio on osallistamisen ja vuorovaikutuksen lisäämistä poliittisten instituutioiden ulkopuolella (Habermas 1996, 305; Dryzek 2000). Deliberaatiolla tarkoitetaan keskustelua, jossa osallistujat ovat tasapuolisessa valta-asetelmassa keskenään ja argumentoivat näkemyksiään yksimielisyyteen pääsemiseksi. Jürgen Habermasin argumentaatioteorian mukaan päätöksenteko nojautuu tällöin paremman argumentin voimaan. Perusteena laajojen toimijajoukkojen mukaan ottamiselle on nähty edustuksellisen demokratian kyvyttömyys vastata ympäristöongelmiin, päätöksenteossa hyödynnetyn tietopohjan monipuolistuminen, hallinnan legitimiteetin ja päätösten noudattamisen paraneminen sekä toimeenpanon sujuvoituminen (Meadowcroft 2004; Bäckstrand ym. 2010; Bäcktrand \& Kronsell 2015, 12; 5; Zografos 2015, 79). Tässä yhteydessä tarkastelen soidensuojelun täydennysohjelmavalmisteluhanketta deliberatiivisena prosessina tapaustutkimuksen keinoin.

Soiden eliölajiston ja suoluontotyyppien uhanalaistuminen on kiihtynyt ja nykyinen suojelualueverkosto ei riitä turvaamaan suotuisaa suojelun tasoa. Suomessa oli ennen soidensuojelun täydennysohjelman toteuttamista yhteensä noin 1,26 miljoonaa hehtaaria suojeltuja suoalueita (Alanen \& Aapala 2015). Soidensuojelun perusohjelmat vahvistettiin vuosina 1979 ja 1980, ja niitä on täydennetty vuosina 1995 ja 2004 (Borg 1984, 13; Kaakinen \& Salminen 2006). Osa suojelusoista sijaitsee kansallis- ja luonnonpuistoissa sekä erämaa-alueilla, ja soidensuojeluverkostoa on täydennetty myös Natura 2000 -ohjelmalla ja vanhojen metsien suojeluohjelmalla (Heikkilä \& Lindholm 2015, 186).

Soidensuojelun täydennysohjelmatyöryhmä, joka kokoontui vuodesta 2012 vuoteen 2015, sai tehtäväkseen suojelualueverkoston laajentamisen. Tavoitteena oli päättää ohjelman aluerajauksesta ja kohdevalintakriteereistä. Työryhmä kokoontui hyvässä hengessä. Työryhmän osallistavan prosessin ja työryhmätyöskentelyn tulokset sivuutettiin osittain toimintapolitiikan valmistelussa (Albrecht \& Åkerman 2016). Hyvä politiikan valmisteluprosessi ei kuitenkaan välttämättä takaa hyvää politiikan toimeenpanoa. Ympäristöministerin vaihdos kesken työryhmäkauden vaikutti valmisteluun sisältöön, sillä kun vihreiden Ville Niinistö poistui ydinvoimakohun seurauksena hallituksesta kokoomuksen Sanni Grahn-Laasonen asetti työryhmän uudeksi tavoitteeksi vapaaehtoisen suojelun toteuttamisvaihtoehtojen selvittämisen. MTK kiitteli tiedotteessaan tekoa mitä parhaimmaksi luonnonsuojeluteoksi.

Luonnonsuojelu ei ole ainoastaan vaihtoehtoinen maankäyttömuoto vaan se on velvoite. Perustuslain 20 §:n on kirjattu, että vastuu luonnosta ja sen monimuotoisuudesta, ympäristöstä ja kulttuuriperinnöstä kuuluu kaikille. Haasteellista tämän lainkohdan toteuttamiselle on tilanne, jossa luonnonsuojelu on ristiriidassa omaisuudensuojan kanssa. Vapaaehtoisen luonnonsuojelun kokeiluilla on pyritty vastaamaan tähän luonnonsuojelun ja omaisuudensuojan ristiriitaan, sillä vapaaehtoisen luonnonsuojelun on katsottu lisäävän suojelun hyväksyttävyyttä. Tämä perustuu kannustusajatteluun, jonka mukaan rahallinen korvaus on tehokkaampi muuttamaan totuttuja toimintatapoja kuin pakko ja herättää vähemmän vastustusta.

Tämä osatutkimus tuo esiin, että soidensuojelun haasteet eivät ole ohi. Vuorovaikutteisen hallinnan näkökulmasta soiden suojelu on mutkikasta, sillä tavoitteista ja keinoista neuvoteltaessa osapuolten on huomioitava useita, osin toisensa poissulkevia intressejä uhanalaisten luontotyyppien ja lajien suojelusta metsätalouden ja turvetuotannon tulevaisuudennäkymiin sekä virkistysarvoihin. 


\section{Ympäristöhallinta}

Virkistyskäyttöarvojen ja suojeluarvojen saadessa lisää painoarvoa, ympäristöhallinta on jakautunut yhä laajemmalle toimijajoukolle (Rannikko \& Määttä 2010). Tämän vuoksi tarvitaan yhä kokonaisvaltaisempia lähestymistapoja vastaamaan ympäristöhallinnan haasteisiin. Tässä tutkimuksessa esiintyvä hallintateoriaan kytkeytyvä tarkastelu korostaa vuorovaikutusta, verkostoja ja prosesseja (Kooiman 2003, Hajer \& Wagenaar 2003). Ympäristöhallinta on haasteellista, sillä yksikään hallinnan taho ei yksin vastaa ongelman ratkaisusta ja eri toimijatahot esittävät erilaisia ratkaisuvaihtoehtoja eri näkökulmista käsin. Ympäristöhallintaan osallistuvat valtionhallinnon lisäksi talouselämän kansalaisjärjestöjen sekä paikallisaktiivien moniääninen joukko.

Deliberatiivisen ympäristöhallinnan lupauksena on, että se lisää osallistumista ja kestävyyttä yhteiskunnassa ja sitä kautta edistää myös ympäristönsuojelua. Kuitenkin deliberatiivisten käytäntöjen yhteydessä on esitetty huoli päätöksenteon laajamittaisesta siirtymisestä demokraattisen kontrollin ulottumattomiin. Muun muassa Erik Swyngedouw (2005) on esittänyt, että muutos perinteisestä hallinnosta hallintaan on jakanut päätöksentekoa ei-valtiollisille toimijoille ja johtanut demokratiavajeeseen yhteiskunnassa. Päätöksentekorakenteissa vaikuttavat valtiollisten toimijoiden sijaan yritysintressit ja professionaaliset toimijat. Tätä kehitystä on kutsuttu jälkidemokraattiseksi tilaksi.

Ympäristönhallinnan haasteisiin on pyritty vastaamaan uudistamalla suopolitiikkaa. Muutosta kuvastaa laajan asiantuntijaryhmän toimesta laadittu suostrategia, jonka tavoitteena on turpeenkäytön ja suojelun kestävyysnäkökulmien uudelleen määritteleminen. Ekosysteemipalvelut valittiin kansallisen suostrategian laatimisen yhdeksi lähtökohdaksi ja strategiatyön pohjalta valmistui ehdotus suostrategiaksi vuonna 2011 (Ehdotus... 2011). Ekosysteemipalvelulähestymistapa tuo soidensuojeluun uuden argumentin, sillä se korostaa hyötyjä, joita luonto tarjoaa ihmiselle. Suostrategia ei sellaisenaan saavuttanut poliittista sitovuutta, vaan turvevarojen kestävän käytön ja suojelun yhteensovittamisesta annettiin valtioneuvoston periaatepäätös vuonna 2012 (Valtioneuvoston... 2012). Valtioneuvoston periaatepäätös soiden ja turvemaiden kestävästä käytöstä ja suojelusta rajaa luonnontilaiset ojittamattomat suot turpeennoston ulkopuolelle. Suoluonnon sällymisen kannalta uusien ojittamattomien soiden käyttöönotto on kestämätöntä. Turpeennosto tuleekin ohjata jo ojitetuille tai luonnontilaltaan muuten muuttuneille suoalueille.

Turpeennostomäärät ovat kääntyneet laskuun 2010 luvulla. Turvetta käytettiin energianlähteenä $15500 \mathrm{GWh}$, mikä on noin kolmanneksen vähemmän vuoteen 2010 verrattuna. Turpeen verotuksessa tapahtuneet muutokset eivät yksinään selitä näin suurta muutosta turpeen energiakäytössä. Yleisemmin hallintakehikossa tapahtuneet muutokset, kuten Euroopan Unionin päästökauppa, Suomen suopolitiikassa tapahtuneet muutokset, sekä pitkittyneet ympäristölupaprosessit ovat lisäksi vaikuttaneet turpeen energiankäytön suosioon. Polttolaitosteknologian korvautuminen uudella ja vanhojen polttolaitosten sulkeminen, kivihiilen edullisempi maailmanmarkkinahinta ja uusiutuvien energianlähteiden suosio vaikuttavat myös tähän kehitykseen. Leudompien talvien ansiosta kaukolämmöntuotannon energiantarve on pienempi.

Samalla kun turpeennostomäärät pienenevät hitaasti, Suomen tulisi varmistaa, että kotimainen turve ei korvaudu kivihiilellä. Bioenergian lisäämistavoitteet eivät välittömästi poista tarvetta turpeennostolle, sillä turvetta seospolttoaineena käyttäviin polttolaitoksiin on investoitu vielä 2000-luvulla. Lisäksi kivihiilen maailmanmarkkinahinta vaihtelee. Turpeennostossa esiintyy myös vuosittaista vaihtelua, sillä viime kesä oli kuiva ja turvetta nostettiin pitkästä aikaa varastoon asti. Tämän lisäksi on huomioitava, että turpeennoston työllistävyysvaikutus on merkittävä varsinkin maaseudulla.

Yhteenvetona voin siis väittää, että suomalaisessa suopolitiikassa tarvitaan laajaa dialogia, jossa huomioidaan useita, osin toisensa poissulkevia intressejä uhanalaisten luontotyyppien ja lajien suojelusta metsätalouden ja turvetuotannon tulevaisuudennäkymiin sekä virkistysarvoihin. Lisäksi suopolitiikassa tulee pyrkiä kohti vahvaa kestävyyttä. Vahva kestävyys vaatii toimijoiden sitoutumista menneiden sukupolvien harjoittaman piittaamattoman luonnonkäytön jättämien jälkien korjaamiseen. Samalla on varmistettava, että suojelutavoitteet toteutuvat ja resurssit ovat riittäviä soiden ennallistamiseen. 


\section{Lähteet}

Alanen, A. \& Aapala, K. (2015) Soidensuojelutyöryhmän ehdotus soidensuojelun täydentämiseksi. Proposal of the Mire Conservation Group for supplemental mire conservation.] 175 s. Reports of the Ministry of the Environment 26/2015, Helsinki. http://hdl.handle.net/10138/158285.

Albrecht, E. (2015) Energiaa vai luonnonrauhaa? Puolesta ja vastaan argumentointi paikallisessa turvekonfliktissa Keski-Pohjanmaalla. (Energy or natural peace? For and against argumentation in a local peat conflict in Central Ostrobothnia). Terra 127(4), 157-168.

Albrecht, E. \& Ratamäki, O. (2016) Effective arguments for ecosystem services in biodiversity conservation - A case study on Finnish peatland conservation. Ecosystem services 22, 41-50.

Albrecht, E. \& Åkerman, M. (2016) Soidensuojelun osallistaminen ympäristöpolitiikan kokeiluna. (Participatory processes of mire conservation as an environmental governance experiment). Alue ja Ympäristö, 45(2), 4-19.

Borg, P. (1984) Luonnon- ja ympäristönsuojelun historiaa. Teoksessa Ruuhijärvi, R. \& Häyrinen, U. (toim.) Ympäristönsuojelu. Luonnonsuojelu ja luonnonvarat. Kirjayhtymä, Helsinki, 7-18.

Bäckstrand, K. \& Kronsell, A. (2015) The green state revisited. Teoksessa Bäckstrand, K., Kronsell, A. (toim.) Rethinking the green state. Environmental governance towards climate and sustainability transitions. Routledge, London, 1-23.

Bäckstrand, K., Khan, J., Kronsell A. \& Lövbrand, E. (2010) The promise of new modes of environmental governance. Teoksessa Bäckstrand, K., Khan, J., Kronsell, A. \& Lövbrand, E. (toim.) Environmental politics and deliberative democracy. Examining the promise of new modes of governance, 3-27. Edvard Elgar Publishing, Cheltenham.

Dryzek, J.S. (2000) Deliberative democracy and beyond: liberals, critics and contestations. 195 s. Oxford University Press, Oxford.

Dryzek, J.S. (2013) The politics of the earth. Environmental discourses. 3rd edition. 270 s. Oxford University Press, Oxford.

Ehdotus... (2011) Ehdotus soiden ja turvemaiden kestävän ja vastuullisen käytön kansalliseksi strategiaksi. 159 s. Soiden ja turvemaiden kansallista strategiaa valmistellut työryhmä, Työryhmämuistio, MMM 2011:1, Helsinki.

Habermas, J. (1996) Between facts and norms: Contributions to a discourse theory of law and democracy. 636 s. Cambridge: Polity Press.

Hajer, M.A. \& Wagenaar, H. (2003) Introduction. Teoksessa Hajer, M.A. \& Wagenaar, H. (toim.) Deliberative policy analysis. Understanding governance in the network society. Cambridge University Press, Cambridge, 1-32.

Heikkilä, R. \& Lindholm, T. (2015) Saarijärven Paavon henki Suomen soilla - Katsaus soiden käyttöön Suomessa. Katsauksia / Terra 127:4, 181-190.

Kaakinen, E. \& Salminen, P. (2006) Mire conservation and its short history in Finland. Teoksessa Lindholm, T. \& Heikkilä, R. (toim.) Finland - land of mires. The Finnish Environment 23/2006, Vammalan kirjapaino, Vammala, 229-238.

Konttinen, E., Salo, M. \& Möttönen, S. (2018) Turvetuotannon sosiaalisen toimiluvan menetys Saarijärven reitillä. Alue ja ympäristö 47(1), 62-78.

Kooiman, J. (2003) Governing as governance. 264 s. Sage, London.

Lempinen, H. (2013) Jos se ei riitä siitä riidellään. Energiaturvallisuuden kieli ja kuvakieli turve-energian markkinaargumentteina. Alue ja ympäristö 42(2), 53-63.

Meadowcroft, J. (2004) Participation and sustainable development: modes of citizen, community, and organizational involvement, Teoksessa Lafferty, W. (toim.) Governance for Sustainable Development: The Challenge of Adapting Form to Function. Edward Elgar, Cheltenham, UK, 162-190.

Pölönen, I. \& Halinen, A. (2014) Turvetuotanto- ja kaivoshankkeiden YVA-selostusten laadunvalvonta (2007-2014) ja puutteiden korjaamismenettelyt. Ympäristöjuridiikeka 3-4, 10-37.

Rannikko, P. \& Määttä, T. (2010) Johdanto: Luonnonvarakysymysten ajankohtaistuminen. Teoksessa Rannikko, P. \& Määttä, T. (toim.) Luonnonvarojen hallinnan legitimiteetti. 295 s. Vastapaino, Tampere.

Ruuskanen, E. (2010) Power and heat from peat - Peat in Finnish energy policy. 171 s. Bookwell Oy, Jyväskylä.

Swyngedouw, E. (2005) Governance innovation and the citizen: The Janus face of governance beyond the state. Urban studies 42(11), 1991-2006.

Tanskanen, M. (2000) Näkyvän takana. Tutkimus metsäojitetun suomaiseman kulttuurisuudesta. 224 s. Julkaisuja No 8., Joensuun Yliopisto, Maantieteen laitos. Joensuun yliopistopaino, Joensuu.

Valtioneuvoston... (2012) Valtioneuvoston periaatepäätös soiden ja turvemaiden käytöstä ja suojelusta. Helsinki \& Periaatepäätös, Valtioneuvosto. 30.8.2012.

Zocrafos, C. (2015) Value deliberation in ecological economics. Teoksessa Martinez-Alier, J. \& Muradian, R. (toim.) Handbook of ecological economics. Edward Elgar Publishing, Cheltenham, UK, 74-99.

\section{Väitöskirjan tiedot}

Eerika Albrecht: Peatland politics in Finland - Local movements, deliberative environmental governance and arguments. Publications of the University of Eastern Finland, Dissertations in Social Sciences and Business Studies No 177. ISBN 978-952-61-2876-4. ISSN: 1798-5749. University of Eastern Finland, Joensuu 2018.

Saatavilla osoitteesta: http://epublications.uef.fi/pub/urn_isbn_978-952-61-2876-4 